\title{
Modern Healthy Lifestyle Miskolc
}

\begin{abstract}
18
ÖSSZEFOGLALÁS: Mit is jelent a gyakorlatban a modern egészséges életstílus? Leginkább azt jelenti, hogy van eszköztáram a stresszel megküzdeni, hogy önmagam tudjak lenni egy olyan világban, amely számtalanszor sok, zajos, nehéz, és talán még veszélyes is. Azt is jelenti továbbá, hogy találok kapaszkodókat, amikor elhatalmasodik a bizonytalanság és a félelem bennem. A mostani tanulmány Miskolc példáján mutatja be azt az összefogást, amely újragondolja a jólléthez való viszonyt. Újragondolja a lakosság és a helyi szolgáltatók szemszögéből, és megkísérli az egészségturizmus megteremtését egy olyan helyen, ahol eddig máson volt a fókusz. A bemutatott mintaprojekt példaként szolgálhat más települések számára is.

Kulcsszavak: egészséges életmód, holisztikus egészség, prevenció, rekreáció, reziliencia, immunerősítés
\end{abstract}

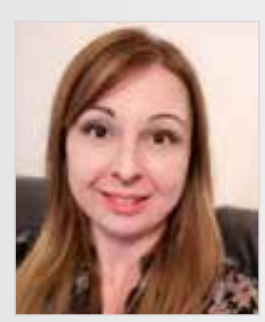

Szerzo", rovatvezetô": MATÓ-JUHÁSZ ANNAMÁRIA Miskolci Egyetem Gazdaságtudományi Kar Whole life balance specialista efkegtur@uni-miskolc.hu egyetemi tanársegéd, Ph.D hallgató

kutatási terület: $\mathrm{Az}$ egészségtudatos magatartás fejlesztése a társadalmi marketing eszközeivel juhasz.ancsa@uni-miskolc.hu

\section{BEVEZETÉS}

Mit is jelent a gyakorlatban a modern egészséges életstílus? Valahogy úgy írnám le, mint azt az életmódot, amely a 21. században fenntarthatóvá teszi a testileg és lelkileg kiegyensúlyozott életvitelt. De miben több és más, mint a hagyományos értelemben vett egészséges életmód? Egyrészt a jóllét értelmezéséig kell visszamennünk, és azt vonatkoztatni az egészségre. Így a holisztikus egészség fogalmát kell a legszélesebben értelmezni. A WHO testi, lelki, mentális és szociális jóllétet definiál már egy jó ideje.

De mit is jelent ez? Ebben a rendszerben a fiziológiai, az érzelmi és a gondolati egészség hármas egységéról beszélünk, míg a társadalmi egészséget egy olyan kapcsolatrendszerként írnám le, amely az embereket körülvevő többi élőlény felé irányuló harmonikus múködésről szól (többi élőlény: a Föld, a flóra, a fauna, a többi ember és a többi ember által alkotott dolgok; harmonikus müködés: tiszteletteljes kommunikáció és magatartás személyes és online térben). Ebből a logikából a jóllét az, amikor a fenti összetevők jól múködnek, vagy ha éppen kibillent állapotban van, vannak, akkor viszonylag rövid idő alatt megvan a lehetőségem és a tudásom arra, hogy a harmóniát vagy belső békét visszaállítsam magamban úgy, hogy közben a környezetemnek nem ártok. Másrészt a modern szó azt a technológiai modernitást jelenti, amely a kor vezető innovációit termékek és szolgáltatások segítségével a kezünkbe adja, mint lehetőséget, hogy a kibillent egészségünket a lehető legrövidebb idő alatt helyre tudjuk állítani vagy saját magunk, vagy valaki segítségével.

Ma, 2021-ben, egyévnyi COVID pandémia és annak következményei után az emberek jóllétének kibillenése valamilyen aspektusból sajnos teljesen kézzelfogható. Az egészségtudatosságnak, valamint az egyéni és kollektív felelősségvállalásnak ilyen mértékü fontossága talán nem is volt még jelen a modern korban. Amikor az emberek „be vannak szorítva” a lakóhelyükre, akkor felértékelődnek a településük és a környékük nyújtotta jólléti szolgáltatások.

A Modern Healthy Lifestyle (MHL) koncepció azoknak az egészségtudatos embereknek szól, akik az életük minden területét, legyen szó munkáról vagy magánéletről, azon elv mentén élik, hogy magukért és a környezetükért felelősséggel tartoznak, magukért és a környezetükért építő 
módon tesznek. Azoknak szól, akik felismerik és érzékelik az egyensúly meglétének fontosságát, és tesznek azért, hogy a kibillenéseket helyrehozzák magukban. Teszik ezt úgy, hogy olyan termékeket, szolgáltatásokat vásárolnak, amelyek célirányosan támogatják az egyensúlyukat, olyan rekreációs tevékenységeket folytatnak, amelyek szintén hatnak az egészség valamelyik aspektusára.

Miskolciként fontos számomra, hogy a lakóhelyemen is lássam és tudjam, milyen lehetőségek nyílnak számomra ahhoz, hogy a lehető leginkább fenn tudjam tartani az életem legtöbb területén az egyensúlyt. Így megvizsgálásra került Miskolc vonatkozásában az MHL-koncepció gyakorlatba való ültetése. Ahhoz, hogy sikeresen elérjük a célt, azaz azt, hogy az életünk különböző területein megvalósuljon az egyensúlyi, nyugalmi állapot, mind a keresletet, azaz a lakosokat, mind a kínálatot, azaz a jóllétünkre hatással bíró szolgáltatókat megvizsgáltam az MHL-logika mentén.

\section{ANYGG ÉS MÓDSZER}

A tervek között az szerepelt, hogy lakossági, kérdőíves felméréssel feltérképezem a miskolciak elvárásait az egészségükkel, az egészségük fenntartásával és helyreállításával kapcsolatban. A szakmai egyeztetések során azonban egyértelmúvé vált, hogy a jelenlegi pandémia olyan hatást fejtett ki szinte mindenkire, ami a magyar társadalom minden tagjánál nagyjából ugyanolyan eredményeket alakított ki, függetlenül a lakóhelytől. Így a primer felmérés helyett szekunder adatokra támaszkodtam.

Amikor az egészséggel kapcsolatban adatokat, információkat kerestem, akkor elsősorban a Népegészségügyi Elemzési Központ Információs Rendszerét néztem meg. A NEKIR 2020-ban is több felmérést végzett a magyar lakosság egészségi állapotáról.

A cél az volt, hogy a leíró (ezen belül a tér-) epidemiológia egységes, nemzetközileg elfogadott módszertana segítségével alapvető információkat nyújtson összehasonlítható indikátorok segítségével a magyar népesség egészségi állapotáról, és az azt befolyásoló tényezőkről különböző területi felbontású szinteken a helyi, népegészségügyi, egészségfejlesztési, vagy akár egyetemi szakemberek, egészségpolitikusok számára. A meghatározott prioritásoknak megfelelően, a „népegész- ségügyi” szükségletek mentén jól tervezhetők a lakosság körében a célzott, racionalizált egészségfejlesztési programok, beavatkozások.

A halálozási adatok között az elsődleges megelőzéssel befolyásolható csoportjába tartozónak tekintették azokat a - nemzetközi referenciák szerint meghatározott - 75 év alatt bekövetkező haláleseteket, melyek megelőzésére rendelkezik az ország bizonyítékokon alapuló, hatékony, elsősorban központi, széles körben szervezett primer prevenciós módszerekkel (Juhász, Nagy, Lomen, Nagy, Papp, Gál, Oroszi, 2020). A felmérés eredményeit az Egészségfejlesztési Irodák elemezték és a megfelelő programokat kidolgozták, vagy folyamatosan kidolgozzák.

Jellemzően a gyerekekre fókuszálnak, de a teljes népesség egészségkultúrájának fejlesztése a célja ezeknek a programoknak. Az eredmények itt nem kerülnek bemutatásra, mert a Modern Healthy Lifestyle koncepcióban azokat a miskolci érintetteket fogom bemutatni, akik a saját munkájukkal a hálózatosodás logikáját követve hozzá tudnak járulni a lakossági jólléthez. Ezt a továbbiakban egy ábrán mutatom majd be.

A további vizsgálatok során számos programterv került a látótérbe, amely a következő 7-8 évben lesz majd elérhető, azonban látni, hogy a prevencióban az egészséges életmód életstílussá alakítása lesz a kulcs. Ez innovatív, újszerü módját jelenti a kommunikációnak és a célcsoport elérésének.

Így abban az esetben is, amikor egy település a lakosai számára kínál egészségmegőrző, egészségfejlesztő szolgáltatásokat, akkor célszerű vendégként, kvázi turistaként tekintenie az emberekre.

Ebből a logikából fakadóan azt is megnéztem, milyen módon változott meg a COVID hatására egy turista elvárása, mert azt gondolom, hogy ezek az elvárások a legtöbb emberben megfogalmazódtak és megjelennek egy szimpla hétköznapi szolgáltatás igénybevételekor is független attól, hogy a lakóhelyén vagy belföldön akár ottalvás nélkül veszi azt igénybe.

Hogyan alakultak át az utazási szokások a COVID után? Egyértelműen kijelenthető, hogy a tudatosság nagyon is megnőtt az emberekben. Míg korábban az utazási, kikapcsolódási döntéseinket az ár határozta meg, a járvány hatására az első döntési pont, hogy elég biztonságos-e az a hely, ahova megyek, a szolgáltatók betartják-e a járványvédelmi intézkedéseket (https://hvg.hu/36o/hetilap36o/2020/ 25/20202505magyar1). A biztonság mindenekfelett áll. Amennyiben egy turisztikai desztináció nem tudja a látogatók biztonságát garantálni, akkor a többi feltétel megléte esetén sem tekinthető versenyképesnek (CSAPÓ TÖRÓCSIK 2O2O). Erról kifejezetten tájékozódik a tudatos fogyasztó (https://hvg.hu/kkv/20200506_turizmus_mtu_koronavirus). Felértékelödik a naprakész informáltság, amihez az írott és a digitális sajtó, valamint a közösségi oldalak fokozott használatán túl kifejezetten a járványügyi helyzet figyelésére kifejlesztett koronavírus-térképek és applikációk állnak rendelkezésre.

A Social distancing és a térigény „térhódítása” eredményezte a túlturizmus eltünését (https://turizmus. com/szabalyozas-orszagmarketing/ a-jovo-turizmusa-a-jovo-utazoja-i1169715). Ez a jelenség kedvez a kerékpáros turizmus, az aktív turizmus, a falusi/vidéki turizmus, az egészségturizmus, az ökoturizmus területének.

Azok a trendek, amelyek már egy ideje erősödtek a turizmusban, úgy mint digitalizáció terjedése, személyre szabott megoldások népszerüsödése, tovább erősödtek, de újonnan is megjelentek prioritások (a felkeresendő desztináció egészségügyi helyzetéről való tájékozódás, rugalmasság fokozott elvárása a turisztikai szolgáltatók részéről). (GÖSSLING et al. 2020). A COVID kifejezetten kedvezett az egyéni közlekedés növekedésének, amelyet az is befolyásolhat, hogy leginkább belföldi utazásokban, belföldi rekreációs tevékenységekben és kikapcsolódásokban lehetett gondolkodni (https://uzletem.hu/biztositas/ a-magyarok-tobb-mint-ketharmadabelfoldi-nyaralasttervez). Mindezek hatására a költéseket is visszafogták az emberek, a pénzügyi kultúrában is egyfajta tudatosságnövekedés mutatkozott. Kérdés persze, hogy a pandémia lecsengése után mi marad meg ezekből a trendekből.

Bármi is lesz a válasz, addig célszerű ezen keresleti igények és persze előírások mentén újraszervezni Miskolcon is a társadalmi jólléthez kapcsolódó kínálatot. A társadalmi jóllét növelését az egészségfejlesztés alapjaira építjük rá. 
Egy adott csoport egyészségfejlesztés-eszköze az egészség helyreállítása és növelése, illetve a mihamarabbi, gyors regeneráció elérése. (Fritz, 2019). Jelen tanulmány szorosan leszúkíti az egészséghez kapcsolódó kínálati szektorra a kérdéskört. Így jutunk el oda, hogy a prevencióhoz kapcsolódó szegmens a legszélesebb kategória, hiszen itt az egészségmegőrzés a cél. Az egész wellnessipar és maga a szépségipar erre épül rá, kiegészítve az élménynyújtás szektorával. Annak érdekében, hogy Miskolc vonatkozásában konkrétumokról tudjunk beszélni, nézzük meg az érintetti kört. (1. ábra)

Miskolci lokáció esetén az érintettek: Magyar Turisztikai Ügynökség, Miskolc Megye Jogú Város, Beutaztatásban részt vevók, Miskolci Egyetem, Magyar Életmód Orvostani Társaság, Közép-Kelet-Európai Rekreációs Társaság, Életmódhoz kapcsolódó szervezetek, Élményt nyújtók, Lakosság.
Felmerül a kérdés, hogy ha a kínálati oldalon újrapozicionáljuk a szolgáltatókat, milyen logika mentén tegyük mindezt, hogyan és hol tegyük elérhetővé a kínálatot. A rendező elv nem feltétlenül az, hogy egy nagy központi épületben tömörüljön mindenki, hanem az, hogy az immunerösítés (testi és mentális), ezáltal a testünk optimális múködése viszonylag stabil legyen, illetve az elváltozások gyorsan helyreállíthatóak legyenek. Mivel itt az a cél, hogy gyorsan visszanyerjük az egyensúlyi állapotot, minden rekreációs lehetőség (mozgásos, szellemi), amit a település tud kínálni, láthatóvá és elérhetővé váljon, és az odaérkező jóllétének fokozását eredményezze.

A rendező elv tehát ez a logika, hogy növelni lehessen az odaérkező jóllétét, még olyan áron is, hogy esetleg a saját szolgáltatásomon túl is ajánlok neki megoldásokat. Ehhez kell az az együttmúködés és hálózat, amely csapattá kovácsolja a pontszerü szolgáltatókat.
A múködési forma és az üzleti modell településenként tud változni.

A kuráció és a rehabilitáció már konkrét orvosi beavatkozásokkal és felügyelettel bíró jelenség. Ez a téma már egy központi csoportosulás, ahol a diagnosztika és az orvosi technológia, valamint szaktudás elengedhetetlen. Ráadásul az eredmények eléréséhez több idő kell, így már bentlakásos rendszerről is kell beszélnünk (kivéve 1 napos sebészet).

Nagyon jó tematika tud lenni a városok esetében az életmódváltó programokra építkezni, mert infrastrukturálisan kevesebb beruházást igényel, mint egy mútétekre specializálódott klinika. Erre számos franchise nyújt lehetőséget.

Ebben a tematikában az a jó, hogy az ilyen szolgáltatásokra érkezők turistaként is funkcionálnak, és sok esetben nem is egyedül érkeznek, így meg tud „teremtődni” az egészségturizmus.

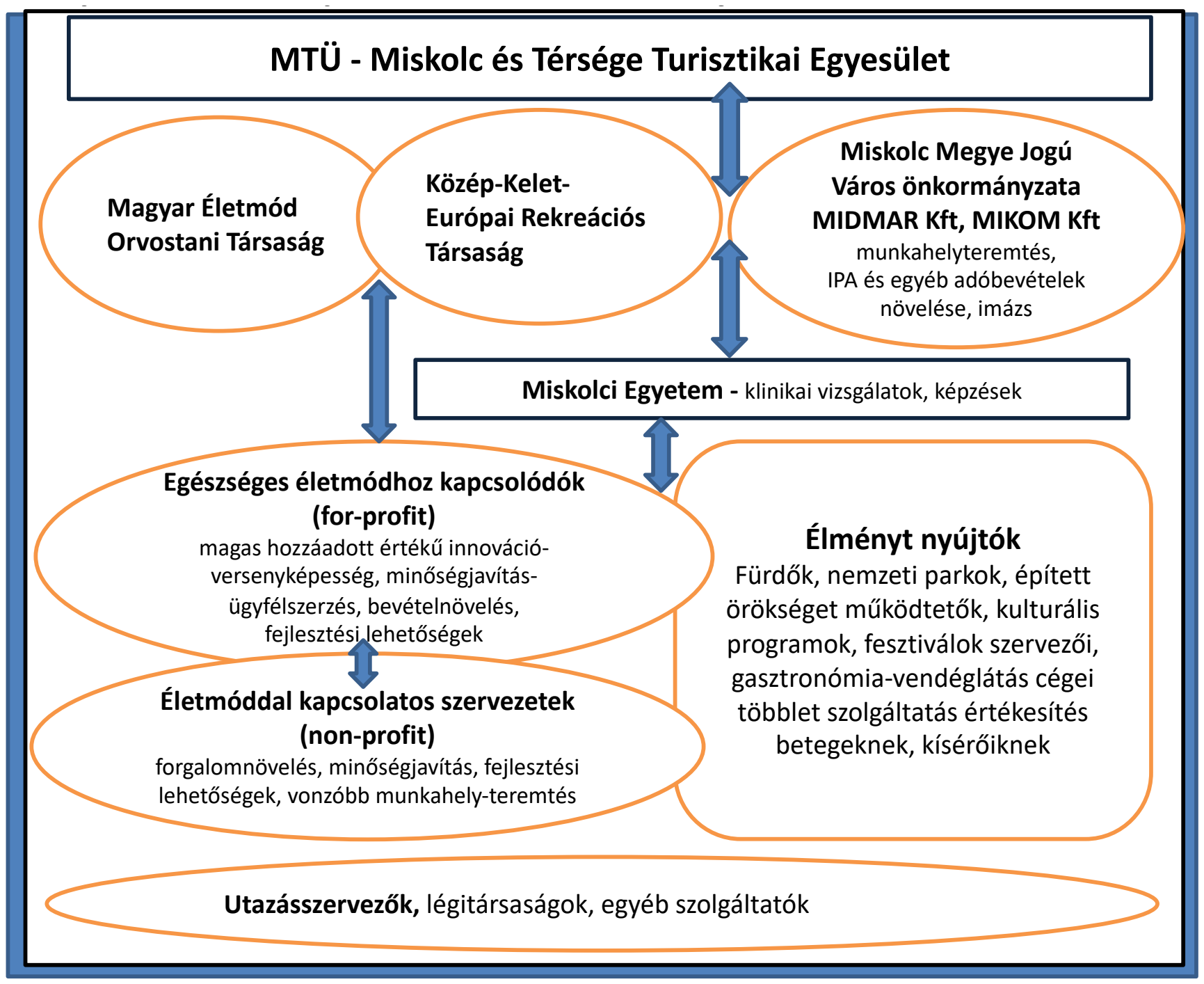

1. ábra: A primer prevención alapuló „turizmus” érintettjei és elvárásaik Miskolcon. Forrás: Saját szerkesztés 
Fordítsuk akkor mindezt le Miskolcra.

\section{A MODERII HEALTHY LIFESTYLE MISKOLC, MINT A2 EGÉSZSÉETURIZMUS MEGTEREMTÉSE}

$\mathrm{Az}$ egyéni felelősségvállalásra, a fenntartható egészséges életmódra építünk, azaz az egyensúly megtalálására, fenntartására.

- Ennek kulcsa az, hogy megtanítjuk arra az embereket, hogyan tudják a modern 21. században magukat kiegyensúlyozni a különböző rekreációs tevékenységekkel, illetve hogyan tudják fenntartani a test-lelki egyensúlyukat, meghosszabbítva az egészségben eltöltött éveik számát.

- Megmutatjuk számukra, melyek a tudomány legújabb vívmányai (termékek, szolgáltatások) ahhoz, hogy otthonukban és a hétköznapjaikban is a saját és a környezetük testi-lelki egészségére maximálisan tudjanak figyelni.

Szakmai interjúk során kialakult az a tematizálása a szolgáltatóknak, amely újrapozicionálja Miskolc kínálatát az egészség(turizmus) jegyében. Megjelennek (1) a diagnosztikában szerepet vállalni tudó szolgáltatók, (2) a különböző egészségmegőrzés témában szolgáltatást nyújtók, (3) a mozgásos és szellemi rekreációban érdekelt szolgáltatók, valamint (4) a holisztikus egészségkultúrát népszerüsítő, edukációt is nyújtók.

A program több lépcsőben valósul meg.

- Az első lépés a pontszerü szolgáltatók hálózatba kapcsolása, amelynek két virtuális felülete indul el márciusban (modernhealthylifestyle.hu és egyensulyazeletben.hu).

- A második lépés egy életmód szálloda indítása, amely előrehaladott tárgyalások fázisában áll. Cél az országos ismertség és elismertség elérése.

- A harmadik lépés a nemzetközi porondra való kilépés az egészségturizmus piacán.

Az újrapozicionálás első szakasza sikeresen lezárult. Az érintettekkel a szakmai interjúk és egyeztetések megtörténtek, azon szolgáltatók, akik elsőként hálózatba rendeződnek, megállapodtak. A második lépés a koncepció és a prototípus kommunikáció. Ennek a szakasznak a megismeréséhez tekint- sük át, milyen kommunikációs csatornák kerültek definiálásra a témában.

\section{A MODERN HEALTHY LIFESTYLE MISKOLC KOMMUNIKÍCCÓJA}

A kommunikációs csatornák 3 nagy csoportját alkalmazzuk: személyes kommunikáció (workshop, kiállítás, study tour, országspecialisták, események) online kommunikáció ( $k p-i$ landing page, social media) és offline kommunikáció (recreation tudományos magazin, felkérö levelek, rádió és tv). A potenciális kereslet online csatornán, a többi stakeholder pedig személyes csatornán és offline módon kerül elérésre.

- két honlap kialakítása folyamban (modernhealthylifestyle.hu és egyensulyazeletben.hu), amelyek rendelkeznek webshoppal is

- a hozzájuk kapcsolódó social media felületek kialakításra kerültek

- az arculati elemek elkészültek, a tájékoztató anyagok rendelkezésre állnak

- Recreation Tudományos Magazinban önálló rovatként múködik

- a Közép-Kelet Európai Rekreációs Társaság Leisure konferenciáin és életviteli klubjain a koncepció megjelenik

- SIXO TV központtal a médiatartalom-gyártás elindul

- a régió és az ország médiumaiba a tartalmak átadására megvan az együttmúködés

\section{KONKLIÚzí}

A COVID világjárvány minden eddiginél jobban felerősítette az egyénekben a saját egészségükért vállalt felelősségérzetet. A pandémia hatására a gazdasági szereplők is újra kellett, hogy gondolják a tevékenységeiket. A kettő (kereslet, kínálat) akkor találkozik a piaci mechanizmusok mentén, ha megvan a közös a nevező. De gondoljuk ezt tovább! Az elmúlt időszak arra is rávilágított mindenkinél, hogy a másokért vállalt felelősségünk is rendkívül fontos, és a környezetünk hogyan és milyen módon hat vissza ránk, a saját egészségünkre és az életünk minden területére. Mondhatnám úgy is, nagy leckét kapott az emberiség. Változtassunk akkor és rendezzük újra a sorainkat. Más prioritások, más határok és más kommunikáció mentén. Erról szól ez a kis cikk. Egy lehetséges utat mutat Miskolcnak, amely példaként szolgálhat mások számára is.

„A cikkben/előadásban/tanulmányban ismertetett kutatómunka az EFOP3.6.1-16-2016-00011 jelü „Fiatalodó és Megújuló Egyetem - Innovatív Tudásváros - a Miskolci Egyetem intelligens szakosodást szolgáló intézményi fejlesztése" projekt részeként - a Széchenyi 2020 keretében - az Európai Unió támogatásával, az Európai Szociális Alap társfinanszírozásával valósul meg."

"The described article/presentation/study was carried out as part of the EFOP-3.6.1-16-2016-00011 "Younger and Renewing University - Innovative Knowledge City - institutional development of the University of Miskolc aiming at intelligent specialisation" project implemented in the framework of the Szechenyi 2020 program. The realization of $t$ this project is supported by the European Union, co-financed by the European Social Fund."

\section{IRODALOMJEGZÉK}

1. Mató-Juhász, Annamária és Dózsa, Csaba és Babai, László és Fritz, Péter és Szántó, Ákos (2020) A Modern Healthy Lifestyle koncepció = The Modern Healthy Lifestyle concept. recreation, 10 (4). pp. 42-45. ISSN 2064-4981 DOI: 10.21486/recreation.2020.10.4.5.

2. Juhász Attila, Nagy Csilla, Lomen Mihály, Nagy Attila, Papp Zoltán, Gál Veronika, Oroszi Beatrix (2020) A Népegészségügyi Elemzési Központ Információs Rendszere (NEKIR), 2020= Information System of Public Health Analysis Centre (NEKIR), 2020, Összefoglaló / Továbbképző közlemény - Review / Educational article, DOI: https://doi.org./10.29179/Eg-

Tud.2020.3.51-84

3. https://hvg.hu/360/hetilap360/2020/25/ 20202505magyar1

4. Csapó János, Törőcsik Mária (2020) THE EVALUATION OF THE ROLE AND IMPORTANCE OF SAFETY AND RISKS IN THE TRAVEL ATTITUDES OF THE HUNGARIAN TOURISTS, Turisztikai tanulmányok, DOI: 10.15170/TVT.2020.05.01.06

5. https://hvg.hu/kkv/20200506_turizmus_ mtu_koronavirus

6. https://turizmus.com/szabalyozas-orszagmarketing/a-jovo-turizmusa-a-jovo-utazoja-i1169715

7. Stefan Gössling, Daniel Scott \&C. Michael Hall (2020) Pandemics, tourism and global change: a rapid assessment of COVID-19, Pages 1-20| Received 06 Apr 2020, Accepted 17 Apr 2020, Published online: 27 Apr 2020 DOI: https:// doi.org/10.1080/09669582.2020.1758708

8. https://uzletem.hu/

biztositas/a-magyarok-tobb-mint-ketharmada-belfoldi-nyaralasttervez

9. Fritz Péter: A rekreáció fogalma, rendszertani felosztása, in: Fritz Péter (szerk.), Alapfogalmak és jelentéseik a rekreació területén: Rekreáció mindenkinek III., Miskolci Egyetemi Kiadó, Miskolc, 2019, 25. 